\title{
Financial Impact of Covid -19 at the International Level
}

\section{Impacto Financiero por el Covid $\mathbf{- 1 9}$ a Nivel Internacional}

GÓMEZ-BRAVO, María De La Luz†*, GOMEZ-BRAVO, Jessica Margarita, ANDRADEOSEGUERA-Miguel Ángel and BARCENAS-PUENTE José Luis

Universidad Tecnológica del Suroeste de Guanajuato

ID $1^{\text {st }}$ Author: María De La Luz, Gómez-Bravo / ORC ID: 0000-0002-8438-2143

ID $1^{\text {st }}$ Coauthor: Jessica Margarita, Gomez-Bravo/ ORC ID: 0000-0003-4037-1925

ID $2^{\text {nd }}$ Coauthor: Miguel Ángel, Andrade-Oseguera / ORC ID: 0000-0002-7926-9162

ID $3^{\text {rd }}$ Coauthor: José Luis, Barcenas-Puente/ ORC ID: 0000-0002-1051-8861

\begin{abstract}
The research is based on the financial impact at the international level of the measures that were taken to prevent the virus from spreading further, without thinking about the impact that this could generate a drop in consumerism for the commercial sectors. Faced with the impact caused in the first months of this year by the pandemic, markets and businesses presented important challenges that they faced by working as a team to be able to cope with the losses, I know they began to present as the fall in demand for their products and services. The situation that is being experienced so far is generating unexpected pressure on working capital and its liquidity.
\end{abstract}

\begin{abstract}
Resumen
La investigación está basada en el impacto financiero a nivel internacional por las medidas que se tomaron para evitar que el virus se propagara más, sin pensar en el impacto que esto podría generar una baja en el consumismo para los sectores comerciales. Ante el impacto provocado en los primeros meses de este año por la pandemia los mercados y negocios presentaron importantes desafíos que enfrentaron realizando un trabajo en equipo para poder sobrellevar las bajas sé que comenzaron a presentar como la caída de la demanda de sus productos y servicios. La situación que se está viviendo hasta el momento está generando una presión inesperada al capital de trabajo y su liquidez.
\end{abstract}

Citation: GÓMEZ-BRAVO, María De La Luz, GOMEZ-BRAVO, Jessica Margarita, ANDRADE-OSEGUERA-Miguel Ángel and BARCENAS-PUENTE José Luis. Financial Impact of Covid -19 at the International Level. RINOE JournalGeneral Economics. 2020. 4-7:1-4

* Correspondence to Author (email: mlgomezbra@utsoe.edu.mx)

$\uparrow$ Researcher contributing first author. 


\section{Introduction}

At the international level, the arrival of the virus called Covid-19 was and is of great importance since it is a disease that so far is not well known, Health officials are determining what this virus can cause in humans. On the other hand, Covid19 is affecting the economy internationally in three different ways 1) directly production 2) causing disruptions in the supply chain 3) financial impact on markets and companies.

The fall in international equity markets when investments are withdrawn causes a great financial impact within the commercial sectors. To such a degree that many companies have been forced to close or even lower the salaries of their employees to $50 \%$, given that the economy in the world fell more than usual, increasing the levels of performance in an untimely manner.

For the international and national markets, it has left millionaire losses in production, raw materials and other aspects within the industrial and commercial market, because the prevention measures that were established led the industrial part to fall several places far below its levels of production.

It is mentioned that more than a third of them are estimating that in order to resume essential operational activities it will take between 6 to 12 months, the financial directors have considered that some companies in order to recover from the financial fall due to the effects of the pandemic could take more than 6 months as previously mentioned that at the national level at the international level a little less because its economic fluidity is a little more liquid.

The year 2020 was the year where the world stopped and that will come to represent the losses of trillions of dollars, taking into account the GDP and the IMF, more than 5\% of the GDP in Mexico and $35 \%$ in the United States for which it is expected that more than 150 countries are facing an economic contraction.

The lack of the vaccine makes the pandemic very fragile and longer, as it is spreading every day and is leading the economic sector into a difficult phase.
The combination of the factors nature of the pandemic, the phase of the economic sector, and the acceleration to adopt technology made the biggest of the economic blows, and where the economic shock hit the most was in jobs since there is a rise in unemployment internationally since it took off from $3.3 \%$ in March for the month of July the rate was at $5.4 \%$

\section{Framework}

At the international level, the effect it caused was an international crisis, companies were advised to take some alternatives to be able to implement new technologies in all their areas.

The WHO declared a pandemic in March of this year when it was affecting all countries and immediately the measures that should be taken to avoid contagion were given, these implemented measures have caused an unprecedented economic crisis.

The IMF mentioned that the pandemic has caused a stagnation in the international economy and a great recession similar to the economic crisis that occurred in 2008, but the OECD mentions that the scenario that is being lived in this year caused the reduction of economic growth international closing with $1.5 \%$. The biggest challenge for all organizations is being able to maintain and reinvent their business models during the pandemic and when it ends.

The means of payment companies such as banks, policyholders and investment funds have been some of the very few companies that their investment funds had growth. Because of the situation that is being experienced internationally.

Internationally, companies have had to intervene in Digital marketing areas in order to increase growth opportunities in their areas and to review business models and keep customers satisfied. Showing the changes made within them to the client. The changes that were made in most of the Companies at the international level affected the client since their products changed in price and some even in quality, they were also affected by the changes since the companies were asked to make their hours longer. 
Reduced when their activities were operational, work from home was implemented for those who were administrative with a variable schedule, all this was implemented to be able to take care of the client and them from COVID-19, the bad thing about this implementation is that the salary was lowered $d$ workers because they did not perform their full working hours.

The majority of the company at the international level did not have any insurance or protection against pandemics, this would have been very helpful to avoid falling into the crisis that it is experiencing at the moment.

Insurers in these times of crisis are in very complicated times and are reporting that they will not solve the clauses that speak about higher risk expenses.

At the international level, the pandemic continues to be a great unknown because no one knows for sure that what will happen when it is going to end, phase 3 is being faced, which has been handled as the most critical since at the moment there is the Very high financial impact where customers, employees and owners are holding the organizations by strings so as not to fail and the pandemic does not end, there are countries that are currently beginning their normal life that gives other countries a lot of hope.

2020 is a year full of experiences that has taught all international and national entrepreneurs to know how to value the value proposition and be able to prepare for the future, now is when they value being able to give more attention to their workers and their clients and thus learn from them.

\section{Development}

The financial impact at the international level by the Covid -19 was terrible for the economy in a few weeks it had collapsed, the banking institutions were pronouncing an economic crisis in the middle of the year 2020. UNCTAD recognized that the duration of the economic crisis at the international level will depend on three major factors 1) The spread of the virus around the world 2) The time for the vaccine to exist 3) the responsibility on the part of the government and private individuals to to be able to carry out strategies and thus pay off the damage caused to the economy.
They should be proposed as efficiency measures and not only in macroeconomic policy but in a whole series of strategies to be able to reform the economy of companies at the international level.

The OCD has mentioned that the pandemic that is currently being experienced brings with it the third and one of the largest economic and financial crises and derived from this a social crisis.

He considers that the main thing to be able to get out of this economic and financial crisis is to regulate the objective and diagnosis of the aforementioned areas. Because the International Monetary Fund has already mentioned that in this year 2020 one of the worst financial crises that have existed in history at the international level will take place due to the COVID -19 pandemic.

The financial impact at the international level is considered due to the large drop in exports that are made throughout the world, as well as the flight of capital and the decline in tourism. With the lag of shocks, it caused the decline within the economy and unemployment caused the largest of the economic restrictions at the international level.

COIVID-19 became more than a monthlong issue, but it could be done for years before everything can return to normal within the economy and at a social level.

Within the economic sectors at an international level, one of the most affected has been the automotive, commercial services, the entertainment industry, hotels, professional services, the aerospace industry and some sectors, on the contrary, had a good performance such as electricity, services online, health, insurance, and banks.

A very significant context at the international level is the social discontent at the international level since there is great frustration due to the lack of opportunities and the inequality that is being experienced.

Within the pandemic, poverty and inequality were growing and today $12 \%$ of people live in extreme poverty at the international level and every day it rises more. 


\section{Methodology}

It will be Qualitative since data collection without numerical measurement is used to discover or refine research questions in the interpretation process, Qualitative studies can develop questions and hypotheses before, during or after data collection and analysis.

Qualitative data make detailed descriptions of situations, events, people, interactions, observed behaviors and their manifestations. The qualitative approach mainly seeks "dispersion or expansion" of data and information, reflection is the bridge that links the researcher.

The qualitative approach studies the various subjective realities constructed in the research, which vary in their form and content between individuals, groups and cultures, reality does change through observations and data collection, describes and interprets the phenomena through perceptions and meanings produced by the experience of the participants.

The qualitative approach provides depth to the data contextualization of the environment and unique experiences, as well as provides a "fresh, natural and holistic" point of view of the phenomena, as well as flexibility.

The orientation towards description, prediction and explanation is directed towards measurable or observable data. The goal of mixed research is not to replace quantitative and qualitative research, but to utilize the strengths of both types of inquiry by combining them and trying to minimize their potential weaknesses.

Mixed methods represent a set of systematic, empirical and critical research processes and involves the collection and analysis of qualitative and quantitative data, as well as their integration and joint discussion to make inferences as a result of all the information collected and achieve greater understanding. of the phenomenon under study.

They are the systematic integration of qualitative and quantitative methods in a single study to obtain a more complete picture of the phenomenon, these can be combined in such a way that the qualitative and quantitative approaches retain their original structure and procedures.

\section{Conclusion}

The financial impact that is being experienced in this year 2020 slows the pace of economic growth at the international level due to the COVID -19 pandemic. The digital economy in the field of artificial intelligence was surprised by the pandemic which took it to a lap within its area.

The most complicated thing about the situation we are experiencing lies in the fact that it is the first time that this situation has happened relatively quickly and some had to be carried out and learning had to be managed due to economic shocks. The fact was that many had to face challenges simultaneously.

The uncertainty that we find ourselves due to the rapid appearance of the virus stopping economic growth at the international level, there were no strategies to be able to solve the problems that began to occur, which led to the dismissal of personnel or lower wages up to $30 \%$, unemployment began to grow internationally, debts as well.

To date, there is no end date for this situation that is going through the world, every day there is talk of more infections, of closing the establishments and companies that are the largest sources of employment. No laboratory has a vaccine to help us fight the virus and as long as the situation does not exist, it will be the same or worse economically and socially, people find themselves with many problems that have led them to seek medical help spending the money that do not have. It is expected that the year 2021 will have a good start and thus the economy can be recovered internationally and also the tranquility of the people.

\section{References}

www.el financiero.com.mx

www.revistamasseguridad.com.mx

www.realinstitutoelcano.org 